\title{
sustainability
}

ISSN 2071-1050

www.mdpi.com/journal/sustainability

Commentary

\section{Sustainability: A Platform for Debate}

\author{
Hilary Tovey \\ School of Social Sciences and Philosophy, Trinity College Dublin, Ireland; \\ E-Mail: htovey@tcd.ie
}

Received: 16 February 2009 / Accepted: 10 March 2009 / Published: 11 March 2009

\begin{abstract}
Sustainability, as a new platform for debating sustainable development, drawing on a range of disciplinary perspectives and knowledges, provides an opportunity to ask some searching questions about this concept. This short paper seeks to remind ourselves of some of the questions we might ask (recognizing that there are also many others). It asks, in particular, about the organisation of work in contemporary societies and the sorts of relations to nature to which this gives rise; the sorts of knowledges which may help us to become more sustainable in our use of natural resources; the most useful modes of knowledge organization, transfer and dissemination for sustainability; and whether 'sustainability' is only or primarily about sustaining nature, or whether it must also include trying to create and sustain a certain kind of society.
\end{abstract}

Keywords: Work-nature relations, knowledge for sustainability, democratic participation.

The terminology of 'sustainability' may be relatively new - it seems to have come into use first in some IUCN reports in the early 1970s, and then spread much more widely with the publication of the Report of the UN World Commission on Environment and Ddvelopment, Our Common Future [1], in 1987 - but the idea is very much older. Karl Marx, writing in the second half of the 19th century, argued that all forms of work (which he saw as the most significant of the ways in which human beings interact with nature) need to include a component of control and regulation which ensures that our use of natural resources and processes to meet human needs is 'rational'. Rational interaction with nature would mean that work is regulated to ensure that the basic conditions which allow nature to continue to reproduce the resources on which we as humans depend are not destroyed in the process of work itself - or, in his terminology, that no 'rift' develops in the metabolic flows and relations which are basic to human and natural survival (Foster 1999) [2].

The tragedy facing human society, in Marx's view, is that our relations with nature through work today are organised in a way which is highly 'irrational' - or as we might say, unsustainable. We 
routinely engage in industrial and technological practices which undermine or destroy the very resources on which we depend, while treating nature as having no intrinsic value and resources as a 'free gift' - either because their use carries no cost, or because the cost can be 'externalised' onto marginal social groups, natural species, and future human generations.

However, Marx did not see this as a necessary and eternal characteristic of all human societies and their modes of organising work and industry. He saw it as a specific consequence of the dominance of a capitalist mode of production. Capitalism, in Marx's view, is incapable of behaving 'rationally' towards nature: its pursuit of markets and profits drives it into a whole series of contradictory relations, both ecological and social, which reveal themselves in a spiral of resource degradation, technological innovation to overcome this, further resource degradation, and a ramifying series of new or additional 'metabolic rifts' leading to new attempts at repair by science and capital.

Whether or not we agree with Marx's identification of capitalism as the source of unsustainability, his analysis does encourage us to pose some very hard questions. Is sustainability a realistic goal for contemporary societies, given that we live in a world organised around global trade and competition on global markets? This is a world in which, at least until very recently, major powerful actors, including global corporations, global regulatory institutions like the World Trade Organisation, national states and regional superpowers, have shared an aspiration towards 'de-regulation' rather than regulation - de-regulation of markets, trade, and business practices, including how businesses organise and oversee processes of work; a world in which deficiencies in natural resources in some, usually core and wealthy, countries are made good every day by importing the natural resources of other, less developed, countries in the form of food, clothing, raw materials for industrial processing, and so on. It is a world in which we 'manufacture' nature (Goodman and Redclift 1991) [3], changing the characteristics and life experiences of natural species to suit our own goals and with little concern about the future impacts of our interventions. From any perspective other than that of profit, it can be hard to find any 'rationality' in the ways in which our contemporary world organises its work on and uses of nature.

Can we, or how can we, find ways to transform this situation? The solution offered to our being trapped on a path of 'unsustainable development' in Our Common Future [1], by and large, was twofold. It called for an increased application of science to the environmental problems beginning to loom large in our faces; and for the building of a consensus and a collective will among all the peoples of the world to change their behaviour towards more environmentally sustainable life practices. The authors of Our Common Future [1] assumed that science itself, as a neutral and value-free search for truth, was widely trusted by ordinary citizens; and that building a commitment to sustainability among citizens was largely a matter of educating them so that they could recognise the scientific facts of environmental damage, and would then act in the appropriate way.

Even in the 20 years or so since publication of the Brundtland Report, these assumptions have begun to unravel. The image of science as neutral towards the emerging global economy with its high dependence on constant technological innovation is no longer so convincing, and social distrust of science has emerged as a significant issue in many societies. Scientific discovery and technological innovation often appear to be inescapably directed and supported by the interests of capital. Capital supports science in the hope of finding a way to overcome the obstacles to profit-making thrown up by natural processes and characteristics - such as the biological life-cycle of plants and animals, whose 
duration over time makes agriculture so much less proftable than industrial forms of production (Goodman et al. 1987) [4]. But what from one point of view is an 'obstacle' can be seen from another point of view as a fundamental ecological process or relationship which is essential to maintaining environmental sustainability. As Ulrich Beck asked in his seminal work Risk Society (1992) [5], since science has been part of the problem, how can it be part of the solution?

Work in sociology, anthropology, and indeed in ecological science itself (e.g. Berkes et al. 2003; Bruckmeier and Tovey 2009; Ploeg 2008) [6-8], has opened up a series of questions around the possibility and the content of 'sustainable knowledge'. What sort of knowledge is most useful to set us on the path towards more sustainable living, how is it best transferred and communicated to others, what are the best social arrangements for ensuring that social learning for sustainability takes place? While we face environmental crises that are in many cases global in reach and consequences, our relations to nature through work and living are still often situated within diverse and locally distinctive ecologicial settings. Western science seeks to produce knowledge which is context-free and transferable from place to place (what Latour 1987 [9] calls the production of 'immutable mobiles'), but it might be that what we most need for sustainable living is a type of knowledge which is 'mutable but immobile', that is, flexible, open to revision, based on and oriented to the experience of working and living within a local ecological context.

A further problem around sustainability concerns what it is that we want to sustain. Is this nature, and if so, in what sense? It may make a difference whether we understand nature as a set of biophysical, ecological or metabolic processes which operate to maintain a stable natural system which can reproduce itself over time, or whether we understand nature as inherently changeable in unpredictable ways. For many people, nature is probably neither of these things but simply the local landscapes, species and climate within which we 'dwell' (Ingold 2000) [10] and whose familiarity is part of what we love about them. But when we speak of 'sustainability' we may also have other goals in mind: perhaps what we want to sustain is society, understanding that our deep dependence on natural processes and resources is critical to but not sufficient for that? How far would we be willing to go, for example, towards creating a society which is dictatatorial, authoritarian and socially exclusive, just in order to secure relations with nature which allow us to continue to survive? This question came onto the 'sustainability' agenda with some force in the aftermath of the Rio Earth Summit in 1992, which added to all the different meanings already attached to the concept of 'sustainable development' the argument that this must also be democratic development: that a 'sustainable society' is one which encourages its citizens - with all of their different orientations to, interests in and knowledges about nature - to 'participate' in the decisions that have to be made to secure a more sustainable future. Or perhaps, ultimately, sustainability is all about the creation of 'sustainable livelihoods'? This brings the focus back to work as a key way in which we interrelate with nature, and the need to find ways of organising work so that we can continue to live from and enjoy nature's resources but without destroying them in the process. Most public discourse about the environment today, however, addresses consumption rather than work, and often in a very individualising way, through notions like 'food miles' and 'ecological footprints'. Should our attempts to move towards a more sustainable future focus primarily on consumption, or on work and production?

'Sustainability' is often represented to us as a goal or an endpoint - something we will have achieved when we have finally brought economy and ecology into a proper relationship, or when we 
have achieved the desired 'balance' between the economic, social and environmental 'dimensions' of development. An alternative view finds some support within Our Common Future [1] itself (p. 9): 'Yet in the end, sustainable development is not a fixed state of harmony, but rather a process of change in which the exploitation of resources, the direction of investments, the orientation of technological development, and institutional change are made consistent with future as well as present needs'. Seeing it as process, we can recognise that sustainability has two components: a process of social learning, in which we need to constantly remind ourselves that nature does not provide us with 'free gifts'; and a process of struggle, because power and interests, as well as simple forgetting, are always likely to disrupt the learning process and force us to start anew. When we shift our gaze from the endpoint to the process, we may start to see that every move in the process is of immense importance in itself. We can start to ask the critical questions about each small step: is this being organised in an equitable and socially inclusive way? Is it open to hearing different perspectives and different knowledges which may offer valuable insights into local ecological processes? Does it support an effective process of social learning for all those involved? Does it carry within itself the seeds of new ways of organising social relations which are most likely to have a lasting impact on human relations to nature?

The questions to be debated are both multiple and vitally important for how our world evolves. What is making our contemporary way of living so unsustainable? How can we intervene to change this? What changes do we most want to see being made? What values should guide our efforts to make the transition to more sustainable work and life practices? As a new journal, Sustainability offers a new platform where the debates can take place, from different disciplinary standpoints and, with sufficient goodwill, in an increasingly transdisciplinary way. We look forward to your participation.

\section{References}

1. World Commission on Environment and Development. Our Common Future; Oxford University Press: Oxford, UK, 1987.

2. Foster, J.B. Marx’s theory of metabolic rift: classical foundations for an environmental sociology. Amer. J. Sociol. 1999, 105, 366-405.

3. Goodman, D.; Redclift, M. Refashioning Nature: Food, Ecology and Culture; Routledge: London, UK, 1991.

4. Goodman, D.; Sorj, B.; Wilkinson, J. From Farming to Biotechnology (a Theory of AgroIndustrial Development); Blackwell: Oxford, UK, 1987.

5. Beck, U. Risk Society: Towards a New Modernity. Sage: London, UK, 1992.

6. Navigating Social-Ecological Systems; Berkes, F., Colding, J., Folke, C., Eds.; Cambridge University Press: Cambridge, UK, 2003.

7. Rural Sustainable Development in the Knowledge Society; Bruckmeier, K., Tovey, H., Eds.; Ashgate: Surrey, UK, 2009.

8. Ploeg, J.D.V. The New Peasantries: Struggles for Autonomy and Sustainability in an Era of Empire and Globalisation; Earthscan: London, UK, 2008.

9. Latour, B. Science in Action; Harvard University Press: Cambridge, MA, USA, 1987. 
10. Ingold, T. The Perception of the Environment: Essays on Livelihood, Dwelling and Skill; Routledge: London, UK, 2000.

(C) 2009 by the authors; licensee Molecular Diversity Preservation International, Basel, Switzerland. This article is an open-access article distributed under the terms and conditions of the Creative Commons Attribution license (http://creativecommons.org/licenses/by/3.0/). 